\title{
上顎洞癌長期経過例の分析
}

一他部位癌長期生存例との対比一

\author{
近藤隆・河辺義孝
}

\section{An Analysis of Long-term Survivors of Maxillary Cancer}

\author{
Takashi Kondo and Yoshitaka Kawabe \\ (Aichi Cancer Center)
}

\begin{abstract}
An analysis of long-term survivors after curative treatment of maxillary cancer in our clinic evaluated the influence of various factors on the prognosis.

The results of combined treatments were promising. It is important to plan treatments which combine irradiation or chemotherapy with surgery.

The authors also analyzed the clinical findings and mental and physical care of elderly survivors of maxillary cancer and compared the results with those in patients with cancers of other regions.
\end{abstract}

Key words: cancer of maxillary cavity, TNM classification, an advanced aged cancer patient, long-term survivor

はじめに

上顎洞癌は幾多の治療法の変遷を経て着実に 治療成績の上昇を来たしており, 現在, 各施設 ではそれぞれ独自性ある治療がなされている が，その基本は手術，放射線，化学療法の組み 合わせにあり，施行時期，重点の置き方などに 工夫がなされている.

全体的には成績上昇は明らかであるが，個々 の症例では難治の場合にもしばしば遭遇し，現 在も上顎洞癌の治療は頭頸部領域にあって困難 なもののひとつであることに変りはない，長期 的視野に立ってこの疾患を眺めた場合，いかな る様相を呈しているのであろうか.

今回，当科に打いて 1965年 1 月より 1979年12 月の間にとり扱った上顎洞癌一次治療例のう ち, 治療後長期間経過した症例をとりあげ，そ
の実態を分析することにより，今後の上顎洞癌 治療上の参考に資したいと思う。

\section{検討項目}

1 ) 対象症例（表 1 ）

1965年 1 月より 1979年12月の間の上顎洞癌一 次治療例のうち治療後 5 年以上経過してからの 死亡例, 28 例, 5 年以上経過して現在生存中の 症例31例の計59例につき検討した。転州は 1984 年12月の時点で判定した。男性33例，女性26例 である。

2 ）上顎洞嵒長期経過例の $\mathrm{T} \mathrm{N}$ 分類（表 2 ）

59例中 T 3 N 036 例 $(61.0 \%$ ） と最多, つ いで T $2 \mathrm{~N} 0$ 15例（25.4\%）で, $\mathrm{N}+$ は 6 例 (10.1\%) と少なく，しかも5 例 $(83.3 \%)$ が N 1 である. 予期されることながら T 4 症例, N 3 症例には長期経過例はみられなかった。他 
方, 喉頭癌のT 4 症例にはわづかながらも長期 生存例の存在するてと, また, 上咽頭癌の N 3 症例は放射線治療にて他部位のN 3 症例よりも 制御されうる率の多いととを考えると上顎洞癌 のT $4, \mathrm{~N} 3$ 症例の予後はきわめてきびしいと 言える.

3）初回治療よりの生存期間（生存例）（表 3 )

1984年12月の特点で, 最高は17年11か月生存 中の症例であり, 各年代ほぼ同数の生存者を有 し，高歯化の問題，平均余命などより今後も大 体同栐な推移を示すむの上思われる。 上顎洞癌 治療成績の再期的な上昇が実現すれば一侍的に は底辺の搪がりがみられようが，やがてはそれ 屯吸収されて全体としてほぼ均等な率で推移し てゆくのであろう。

\section{4 ）生存症例の现在年齢構成（表 4 ）}

生存症例の現在年榆样成は50歳代10例（32.3 \%)，60歳代11例（35.5\%)，70歳代 7 例（22.6

表 I 上顎癌長期経過例

1 期䦌 : $1965.1 \sim 1979.12$

2 症例 : 59 例 $\left\{\begin{array}{l}\text { 男性 }: 33 \\ \text { 女性 }: 26\end{array}\right.$

3 転㴆 : 生存: 31 例

(1984. 12) 死亡 : 28例

4 性・年拎別分布

\begin{tabular}{|c|c|c|c|c|c|c|}
\hline & $30 \sim 3$ & & & & 勇 & 計 \\
\hline 男性 & 4 & 11 & 10 & 7 & 1 & 33 \\
\hline 女性 & 0 & 6 & 8 & 8 & 4 & 26 \\
\hline 計 & 4 & 17 & 18 & 15 & 5 & 59 \\
\hline
\end{tabular}

表 2 上㖽癌長期経過例の $\mathrm{TN}$ 分類

\begin{tabular}{|c|c|c|c|c|c|}
\hline$T$ & N 0 & N 1 & N 2 & N 3 & 計 \\
\hline $\mathrm{T} 1$ & 2 & 0 & 0 & 0 & 2 \\
\hline T 2 & 15 & 0 & 0 & 0 & 15 \\
\hline T 3 & 36 & 5 & 1 & 0 & 42 \\
\hline T 4 & 0 & 0 & 0 & 0 & 0 \\
\hline 計 & 53 & 5 & 1 & 0 & 59 \\
\hline
\end{tabular}

\%)，上60歳代，70歳代で全体の $58.1 \%$ を占め ることになる。

5 ）死亡壯の年諭（表 5 ）

一方, 死亡歭の年㱓でも50歳代 5 例（17.9 $\%), 60$ 葴代 9 例 $(32.1 \%), 70$ 歳代 8 例 (28.6 $\%), 80$ 歳代 4 例 (14.3\%) のごとく高齡者集 団を形成しているので全身管理による併発症の

表 3 初回治療よりの生存期間 (生存例)

\begin{tabular}{|c|c|c|c|}
\hline 5 & ～ 6 年 & ………… & 5 \\
\hline 6 & ～ 7 年 & 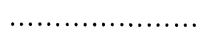 & 4 \\
\hline 7 & ～ 8 年 & … & 3 \\
\hline 8 & 〜 9 年 & …............... & 2 \\
\hline 9 & ～10年 & 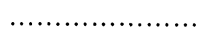 & 2 \\
\hline 10 & ～11年 & …............. & 1 \\
\hline 11 & ～12年 & ……............ & 0 \\
\hline 12 & ～13年 & 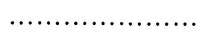 & 1 \\
\hline 13 & ～14年 & $\ldots \ldots \ldots \ldots \ldots \ldots \ldots$ & 2 \\
\hline 14 & ～15年 & …................ & 3 \\
\hline 15 & ～16年 & ㅅ․ & 2 \\
\hline 16 & ～17年 & …........ & 4 \\
\hline 17 & ～18年 & …................ & 2 \\
\hline
\end{tabular}

表 4 生存症例の現在年栯構成

(1984. 12)

\begin{tabular}{|c|c|c|c|c|c|c|}
\hline 年粦 & $40 \sim 4$ & & & & $\begin{array}{r}才 \\
0 \sim 89\end{array}$ & 計 \\
\hline 男性 & 3 & 8 & 5 & 2 & 0 & 18 \\
\hline 女性 & 0 & 2 & 6 & 5 & 0 & 13 \\
\hline 計 & 3 & 10 & 11 & 7 & 0 & 31 \\
\hline
\end{tabular}

表 5 死亡時の年旙

\begin{tabular}{|c|c|c|c|}
\hline 40 & 〜 49才 & ......... & 2 例 \\
\hline 50 & 〜 59才 & (.). & 5 \\
\hline 60 & $\sim 69 才$ & ………… & 9 \\
\hline 70 & 〜 79才 & ………… & 8 \\
\hline 80 & 〜 89才 & . & 4 \\
\hline
\end{tabular}


防止抑制, 再発, 転移, 重複癌の早期発見はも とより高齢者グループとしての生き甲斐ある生 活をも含めた患者管理が必要である.

\section{6 ) 病理組織学的分類 (表 6 )}

扁平上皮癌 54 例, 腺様のう胞癌 4 例, 乳頭状 腺癌 1 例で, 角化度分類は Grade ( I, II) 42例（77.8\%）と大半を占好ている．低分化型

(Grade III, IV) は生存症例 $2 / 27$ (7.4\%), 死亡症例 $7 / 27(25.9 \%)$ 之後者に多くみられ た.

7 ）生存症例の初回治療内容とその経過（表 7)

表 6 病理組織学的分類

A）届平上皮癌…………………54 例

\begin{tabular}{|c|c|c|c|}
\hline & 生存症例 & 死亡症例 & 計 \\
\hline $\mathrm{G}-\mathrm{I}$ & 14 & 11 & 25 \\
\hline $\mathrm{G}-\mathrm{I} \sim \mathbb{I}$ & 2 & 1 & 3 \\
\hline $\mathrm{G}-\mathbb{I}$ & 7 & 7 & 14 \\
\hline $\mathrm{G}-\mathbb{I} \sim \mathbb{I I}$ & 2 & 1 & 3 \\
\hline $\mathrm{G}-\mathrm{III}$ & 2 & 4 & 6 \\
\hline $\mathrm{G}-\mathbb{I I} \sim \mathbb{N}$ & 0 & 2 & 2 \\
\hline $\mathrm{G}-\mathrm{I}$ & 0 & 1 & 1 \\
\hline
\end{tabular}

当科における上顎洞癌治療の推移を示す内容 の治療がなされ，29例は初回治療のみにて制御 され， 1 例の原発䒩再発 (全摘出 $\rightarrow$ 照射)， 1 例の頸部転移（三者併用）はそれぞれ小線源治 療, 頸部郭清術により制御され生存中である。

8 ）死亡までの期間と死因（表 8 ）

初回治療後 5 年から 7 年の間に死亡した 12 例 中 5 例 $(41.7 \%)$ は腫場死で原発腫愓死 3 例, 肺転移死 1 例，原発および頸部腫瘍死 1 例であ った．28例中26例（92.9\%）が治療後11年まで

表 7 初回治療内容とその経過

(生存症例)

\begin{tabular}{|c|c|c|c|c|}
\hline 治療内容 & $\begin{array}{l}\text { 初回治療 } \\
\text { 知て制御 }\end{array}$ & 再発 & 転移 & 計 \\
\hline 全 摘 & 4 & & & 4 \\
\hline 全摘 $+\mathrm{Ra}$ & 2 & & & 2 \\
\hline 前照射 $\rightarrow$ 全摘 & 1 & & & 1 \\
\hline 照＼cjkstart射 & 3 & & & 3 \\
\hline 全摘 $\rightarrow$ 後照射 & 1 & $※ 1(\mathrm{Ra})$ & & 2 \\
\hline $\begin{array}{c}\text { 照射 }+ \text { 化療 } \\
\text { (全 身) }\end{array}$ & 3 & & & 3 \\
\hline 三者併用 & 10 & & $※ 1$ (頸郭) & 11 \\
\hline $\begin{array}{c}\text { 減量 + 照射 } \\
\text { (動注なし) }\end{array}$ & 5 & & & 5 \\
\hline 計 & 29 & 1 & 1 & 31 \\
\hline
\end{tabular}

表 8 死亡までの期間と死因

\begin{tabular}{|c|c|c|c|c|c|c|c|}
\hline 期間 & 腫煌死 & 心不全死 & 脳出血死 & 肺炎死 & 衰弱死 & 不明 & 計 \\
\hline $5 \sim 6$ 年 & 2 & 2 & 1 & 1 & 1 & 1 & 8 \\
\hline $6 \sim 7$ 年 & 3 & & & & 1 & & 4 \\
\hline $7 \sim 8$ 年 & & 2 & & 1 & 3 & & 6 \\
\hline $8 \sim 9$ 年 & & & & & 2 & & 2 \\
\hline $9 \sim 10$ 年 & 1 & & & & & & 1 \\
\hline 10 11年 & & 1 & 1 & & 3 & & 5 \\
\hline 11～12年 & & & & & & & \\
\hline 12 13年 & & & & & & & \\
\hline 13〜14年 & & & & & & & \\
\hline 14 15年 & & & & & 1 & & 1 \\
\hline 15～16年 & 1 & & & & & & 1 \\
\hline 計 & 7 & 5 & 2 & 2 & 11 & 1 & 28 \\
\hline
\end{tabular}


の間に死亡し，結局，他因死は21例（75.0\%） であり，衰弱死はまづ止むを得ないとしても， 心, 肺疾患, 脳血管疾患などは家人の協力も求 めて, 必要な治療が逐行できるよう, 極力, 他 因死例の成少をはかるため，とすすれば戦重な 患者管理からはずれがちな 5 年以上経過例にこ そ，より一層てまやかな日を注ぐ必要がある。

9 ) 死亡症例の初回治療内容とその経過（表 9 )

28例14例（50.0\%）は初回治療にてそのまま 制御され,のこり 14 例は後日, 原発䍒再発11 例, 頸部転移 2 例, 肺転移 1 例を生じた。 全摘
十後照射例では眼䆚を含む上方，外側方に再発 し, 眼球保護による上方部線量の増加, 照射十 全摘例では照射効果により手術範囲を縮小した 症例の存在, 照射単独例では開洞プローべ採取 のみにとどまらず，積極的な腫瘍減量操作に よる低酸素圧癌細胞の除去を計るべきであっ た。この経験は以後の上䕱洞癌治療に反映され た.

10）再発・転移の治療（死亡例）（表10）

表 10 のごとき二次治療により14例中10例 （71.4\%）は制御し得たが，この10例中, 後日
表 9 初回治療内容とその経過

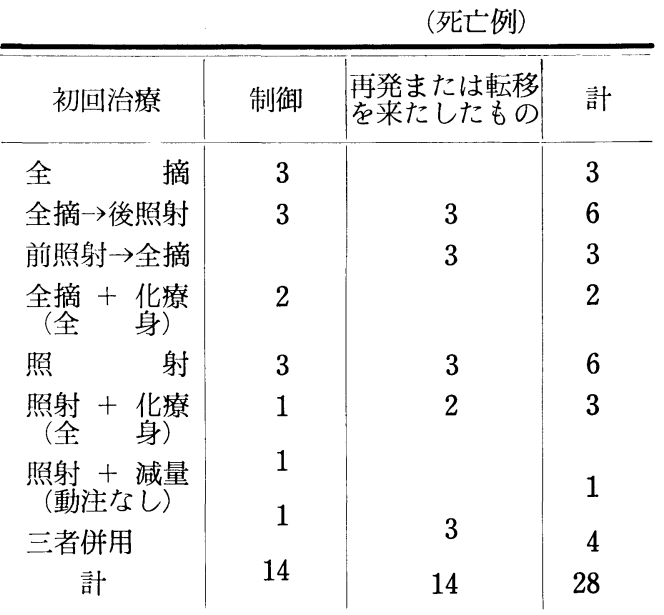

表10 再発・転移の治療 (死亡例)

\begin{tabular}{|c|c|c|}
\hline 治療内容 & 制御 & 非制御 \\
\hline 上顎搔爬 & $1_{* 1}$ & \\
\hline 上顎搔爬 + 外照射 & $2 * 1$ & 1 \\
\hline 上顎搔爬 + Ra & $1_{* 1}$ & \\
\hline 全＼cjkstart摘 & 1 & \\
\hline 外 照射 & $2 * 1$ & \\
\hline 部＼cjkstart切 & & 1 \\
\hline $\mathrm{Ra}+$ 外照射 & & 1 \\
\hline $\mathrm{Ra}$ & 1 & \\
\hline 頸郭 & 2 & \\
\hline 化療 & & 1 \\
\hline
\end{tabular}

表।I 長期間経ての再発・再々発・転移例

\begin{tabular}{|c|c|c|c|c|}
\hline & 初回治療 & $\begin{array}{l}\text { 再発・転移までの } \\
\text { 期間と治療 }\end{array}$ & $\begin{array}{l}\text { 再々発・転移までの } \\
\text { 期間と治療 }\end{array}$ & 転帰 \\
\hline (ㅅ) & 全摘 $\rightarrow$ 照射 & $\begin{array}{l}4 \text { 年 } 3 \text { ケ月 } \\
\text { 貨郭 }\end{array}$ & & 制 御 \\
\hline (우) & 照射 $\rightarrow$ 全摘 & $\begin{array}{l}2 \text { 年 } 4 \text { ケ月 } \\
\text { 上顎挱爬 } \\
\text { 照射 }\end{array}$ & $\begin{array}{l}4 \text { 年 } 1 \text { ケ月 } \\
\text { 本人・家人の希望 } \\
\text { により自宅療養 }\end{array}$ & 非制御 \\
\hline (우) & 照射 $\rightarrow$ 全摘 & $\begin{array}{l}9 \text { ケ月 } \\
\text { 上顎搔爬 } \\
\mathrm{Ra}\end{array}$ & $\begin{array}{l}7 \text { 年 } 8 \text { ケ月 } \\
\text { 照射 } \\
\text { 化療 }\end{array}$ & 非制御 \\
\hline$(\hat{\delta})$ & 照 射 & $\begin{array}{l}9 \text { ケ月 } \\
\text { 上顎蛍爬 } \\
\mathrm{Ra}\end{array}$ & $\begin{array}{l}12 \text { 年 } 5 \text { ケ月 } \\
\text { 凍結 } \\
\text { 化療 }\end{array}$ & 非制御 \\
\hline (令) & 照 射 & $\begin{array}{l}4 \text { 年 } 5 \text { ケ月 } \\
\mathrm{Ra} \\
\text { 照射 }\end{array}$ & & 非制御 \\
\hline
\end{tabular}


三次治療を必要としたものは 4 例で，うち 1 例 のみ制御し得た。

11）長期間経ての再発・再々発・転移例（表 11)

該当症例は 5 例で制御し得たのは 1 例であっ た，長期の空白期間をもち，忽然と受診した之 きにはすでに進行病変で積極的加療ができなか ったのが現実である．治療終了後長らく潜在の 状態にあったものが突如として発症してくるメ カニズムは不明であり, 病理組織上も特徵はな かった，結局，加柃とともに高秢者にみられる homeostasis の破綻により生体抑止機構が解 除されて腫瘍顕現性を回復したものと推論した い.

12）進展方向別分類（T $3 \mathrm{~N} 0$ 症例）（表12）

同一丁範疇症例でもその進展方向により成績 の異なることはすでに報告した。すなわち，前 方向型に比して後方向型の予後は不良であるこ とは否めないが，予後不良型でも長期生存の可 能性はあるので, 初回治療, 追加治療とも徹底 を期すべきである.

\section{考按}

上顎洞癌の治療は全摘出術, 放射線照射（外 照射，腔内照射）の単独または併用に始まり， 幾多の試行を経ながらその時期最邀と思われる 治療を積み重称て現在の手術療法, 放射線療法, 化学療法の組み合せによる集学的治療へと発展 し, 最善の治療法を求めて各施設で研究がつづ けられている. 生活様式, 環境, 健康への関心

表12 進展方向別分類

(T 3 N 0 症例)

\begin{tabular}{c|c|c}
\hline \hline 症例 & 生存症例 & 死亡症例 \\
\hline 進展方向型 & 4 & 6 \\
前方向型 & 3 & 2 \\
上側方向型 & 2 & 1 \\
下側方向型 & 3 & 3 \\
上内方向型 & 4 & 2 \\
下内方向型 & 2 & 2 \\
後方向型 & 1 & 1 \\
全方向型 & &
\end{tabular}

の程度など時代とともに発癌形態も異なり，増 加傾向を示す癌，減少傾向を示す癌と大きくふ たつに分かれて流れ始めた現在，上顎洞癌はど ちらかと言えば後者の流れに入るが，一旦，発 癌すれば難治な疾患であるだけに充分な対応が のぞまれる.

酒井 ${ }^{1)}$ は自己の上顎洞癌治療の变遷について 述べ，各年代別治療内容とその 5 年䇣積生存率 など詳細に検討するととによりつぎの年代への 治療の足掛かりを求め, 癌治療においては流行 の治療法にとらわれず，医師は終始変ら好着実 な努力, 強靮な信念, 謙虚な反省を必要とし, 前の特期に治療した経験から最適と判断した治 療法はつぎの時期には臆せず適用し，順を追っ たトライアルの積み重ね, 地味な歩みこそ最 屯大切であると述べている．癌治療を志すむの にとってふかく至言としてうけとめ，日常診 療, 研究にあたるべきである，他部位の癌も含 めて長期生存の観点よりみてみると堀内ら ${ }^{2)}$ は 放射線治療後の口腔領域扁平上皮癌 645 例（舌 癌 272 例, 口腔底癌 68 例, 煩粘膜癌 66 例, 下雪 肉癌 118 例, 上顎歯硬口蓋癌 59 例, 中咽頭癌 62 例）のうち 5 年生存は 261 例 $(40.5 \%)$ と述べ, 5 年以降に死亡した 104 例のうち原病死は23例 (22.1\%), 重複癌死16例 (15.4\%), その他に よる死亡65例 $(62.5 \%)$ で，65歳以上高齿者群 ではその後の管理が充分なためか天寿を全うす るものが多く，一方，50〜60歳群では重複癌こ とに呼吸器，上部消化管に多くみられるのでこ の点に留意した長期間にわたる慎重な経過観察 が必要としている.

また，食道癌は 5 年生存率が外科療法で $20 \%$ 前後，放射線治療で 5 〜 10\%位であるが，晴山 $ら^{3)}$ は胸部, 腹部食道癌根治照射施行 115 例中 12 例（10.4\%）飞 5 年以上長期生存を認め, 長 期生存例に特有な腫瘍占拠部位は認めず，X線 型では腫瘤型, 表在型の予後が良好でラセン型 は不良であり，大きさでは $5 \mathrm{~cm}$ 以下のあのに予 後が良い傾向がみら礼，5年生存者にて 6 局 所再発のみられることより（全国統計 $13 / 52$, 
$25.0 \%$ 再発率）長期にわたる再発への監視が必 要であり, 治療洏では放射線令髄ならびに心障

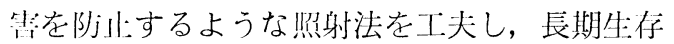
者への配虫が必要であるとしている。

楠元ら ${ }^{4)}$ は発青が早く，早期に転移を生じる ため肺癌のなかでももっとも予後不艮な㸬小絒 胞癌に対して化学療法, 放射緗療法, 免将療法 の併用により，再発，枟移なく 7 年問生存山の

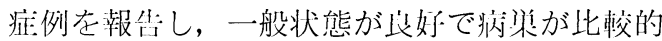

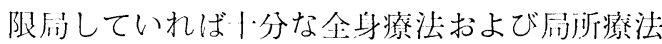
により治療せしめ得る肺小紃胞擂むありうると 述心゙るなど腫陽の各部位において治療法の進步 改棓，診断法の问上とともに長期生存例が今後 増加すると思われ，治療に入る前よりこれらの ことを想定して治療法を配䍐する（たとえば照 射野，照射量など）乙とがより一厛要求される ことになろう．難治炊患のひとつである上顎润 癌の治療に求いても癌細胞を 0 にする，あるい は極力 0 に近づけんとする治療に耐えうる一般 状態の艮好さと，正常な絒胞性伀疫が保持され ていれば初回治療につづく維持療法, 再発, 転 移に対する迎㞦治療むのり切ることができ，長 期間生存せしめるととも十分可能であると思わ れる．癌の治䝤を志すものにとって長期生存症 例の増川は栄極の目的であるが，上顎洞癌の㭶 合はいかなる様相を呈しているのであろうか. この分析が今回の目的である.

検詩対象は1965年 1 月より1979年12月の間の 当科に括ける上顎洞癌一次治療例 196 例のう ち, 治療後 5 年以上経過してから死亡した症例 28例，治療後 5 年以上経過して现在なお生存中 の症例 31 例，計59例（30.1\%）である（表 1 ).

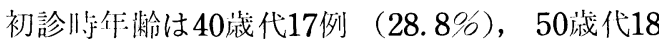
例 $(30.5 \%) ， 60$ 戱代15例（25.4\%）之ほぼ同 摔で，平均余价の閌題よりしても70歳代は 5 例

(8.5\%) と少ない。一般に嵒の惩性度とは別 に長期生存する可能性として平均人价が䦥係 し，初回治療將の年秢がより若いうが嵒の除去 ができた状態を考えれば，より長期に生存する 可能性がある，長期経過例に性による偏りはみ
られなかった。

当該期間に打ける全症例の $\mathrm{N}+$ 率は $20.1 \%$ であったが，長剘経過例のそれは $10.1 \%$ と半数 で，しかも大半がN 1 である，Nの和度が予後 に阙!与すのは站项部创域癌のみならず他部位 癌にても同椂で，中野ら5) は传道癌放射線単独 根治治療例60例（腫瘍長径 $5 \mathrm{~cm}$ 以下 25 例， 5 ～ $10 \mathrm{~cm} 35$ 例）のうち 5 年以上の長剘生存例は 7 例 （腫煬径 $5 \mathrm{~cm}$ 以下 5 例）で，1例の脳苁中死以 外は再発，転移なく生存中であり， $\mathrm{N}$ との阙係 については外科治痖成績の本那集計報告より表

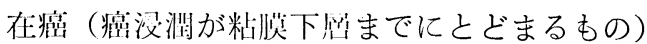
223 例のうち早剘癌（表在癌でリンパ節転移の ないもの）は177例（79.4\%)，つまり（N+） 表在癌は 46 例 $(20.6 \%$ ) で，早期癌の相対 5 年 生存率は $69.7 \%$ と良好なのに反して, $(\mathrm{N}+)$ 表在癌のそれは $33.6 \%$ と劣り， $(\mathrm{N}+),(\mathrm{N}$ 一）は予後に大きく関係する因子であり，症例 数は少ないが放射線治療による stage I 症例

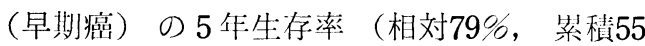
\%) あ良好であることより早期癌では放射線単 独治療の有用性を述べている，上顎润癌におい ては残念ながら飭道澏のごとく集検による早期 病変例抽出の段階には至らず，診断確定將すで に進行例であることが多く，長期生存させるに はかなりの困難な面屯伴う。さらに原発部位

（T）の進行症例は同時に頸部転位（N）も進 行例であることが多く，ての点，たとえば上咽 頭癌においては $\mathrm{N}$ の進行例でも $\mathrm{T}$ の小病变例の ため制御可能例の存在するのに反して，上䫟洞 癌では $\mathrm{T}$ む $\mathrm{N}$ 同侍に進行例であることが多く 制御を困難にしている。 5 年以上経過生存 31 例 の T N分類では T $3 \mathrm{~N} 0 ， 19$ 例(61.3\%), T 2 $\mathrm{N} 0,9$ 例(29.0\%), $\mathrm{T} 1 \mathrm{~N} 0,1$ 例, $\mathrm{N}+$ は 2 例（N1，N 2 各 1 例）であり，一j， 5 年 以上経過死亡28例では T $3 \mathrm{~N} 0,17$ 例(60.7\%), T $2 \mathrm{~N} 0,6$ 例 (21.4\%), T $1 \mathrm{~N} 0,1$ 例, $\mathrm{N}+$ は 4 例ですべてN 1 であり, 死亡群に $\mathrm{N}+$ の 率がやや多かったがとくにきわ立った差はみら れなかった。 上顎润癌M1では長期生存はまづ 
あり得ないが，きわめて稀な埸合として小池 $ら^{6)}$ は上顎癌（adenoid cystic carcinoma）に て初回治療後 3 年目に肺転移を生じ, 化学療法 施行するも効果なく，以後とくに秥極的に加療 しなかったが，その後 8 年間生存した症例资報 告し, 非扁平上皮癌の場合遠隔転移を生じてい ても腫煌增殖が緩慢なため二次障㫪発生が致命 的因子となるのに時間を要するためとした。例 外的にはM 1 症例でも長期生存の㙞合むある が，一般的にはこのようなととは剘待できな い，免疫療法の発展により担癌生体のまま生活 する，つまり生体との巧みなバランスが保たれ ればさらに長骫生存例が增川するであろうが急 には㘹めない。

生存症例の初回治療よりの生存期間は表 3 の ごとく各作代ほぼ均等に分布し, 议高は17年11 か月生存症例である. 癌の政㪇がすすむにつれ て長期生存例は増加し, やがては癌の根絶も剘 待されるが，最近，「対がん10ケ年総合戦畍」 なる施策が発表され，その目愫は10年を目途に 癌の本態解明を図ることにあり，その歰本广策

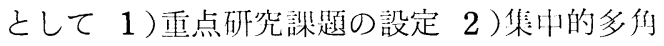
的经究の推進 3 ) 若年研究者の䘚成, 活用 4) 日米を中心とした四際協力の推進 5 )実験 材料の供給等支援体制の整湖の 5 つを揭げ，癌 という疾病の性所上，単純に年次計西西を定めず 柔軟に対忍し, 常に戦略の進捗状沉主平価し, 見直しを行うことも必要であるとしている77. 米国ではアポロ計画につづくナショナル・プロ ジェクトとして1971年 National Cancer Act を制定し，癌対策にとりくんでいるが癌の本態 は未だ完全には解明されていない，癌による死 亡がトップとなった現在，少しであ早くその本 態を解明し, 適確に治療に結びっけ, 癌の恐怖 より解放された多くの長期生存者を作りだすこ とは何者にあ優先した囦家的施策としてとりあ げられね枚ならない。現在, 生存中の人屯, 死 ししている人も死亡時の年齢よりして高秢者集 団である（表 5 ).

撖重な全身管理による併発症の防止, 再発,
転移，禹複癌の早期発见とともに高踰者グルー プとしての生き甲斐ある生活をも目指さねばな らない，癌治療の進少により宮桠者生:存症例が 増えてく机ば，当然そこには重複嵒発生:の問題 がうかびあがってくる，もっとも重複頻度の高 い胃癌が発生した埸合，その対策はいかにある べきか. 紀藤ら ${ }^{8)}$ は高菊者胃癌の手術成績の検 讨で 270 例の 70 歳以上の高歯者胃癌の手術にて 1975年〜1979年の間では全症例数に占める制合 は13.2\%（133/1005）と增加傾向を示している が，手術㨁接死亡率は $0.8 \%(1 / 133)$ 乙著明 飞低下し，5年粗生存率では70〜 74歳 $51.9 \%$, 75〜 79歳66. $0 \%$ で高齢者程成績がよく, 相対生: 存率でみると両群の差はさらに大きいとし, 会 併症対策も充分とられうるようになってきた悓

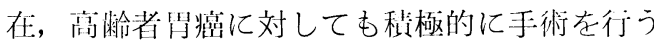
べきと述べている，上龥洞癌患者に生:じる国裮 癌として现段階では罱癌がもっとも考えられる ので，長期生存例に対しては胸部，胃部の定期 検診の施行により早剘病変の発胃に烃如，治療 は根治を目的とした治療手段を採用すべきであ る.

1984年のわが国の平均寿价は男74.54年，女 80.18 年で前年に比べ男 0.34 年，女 0.40 年の仲 びを示し，男文とも世界一の長为国である （男，2 位，アイスランド73.91年，女， 2 位， スエーデン79.61年).

これは1984年の死亡率が男女ともほとんどす べての年齢を通じて改善されたためである．菱 沼 ${ }^{9)}$ は長奶将代の中味を判定するもっとも適切 な指㮐のひとつである㚘价中位数（同侍に生ま れた集団が丁度半減する年秢）を挙げ，女の平 均头命がはじめて70歳を超えた1960年の寿价中 位数は男70.66, 女75.44であったが, 1984年で は男77.90, 女83.19 と男久とも 7 年以上の仲び を示し，長就侍代に突入すると，ある年秢を超 える高齢者が大巾に増加し，なかには植物人間 はもとより，誛たきり，ボケ痴呆になる人もあ ろうが，笑学の進歩，ヘルス・チェック・シス テムの普及, 各自の摂生などにより, その出現 
を抑える可能性は十分にあるとしている．ま た，国連人口部では総人口に対する65歳以上人 口の制合が， $4 \%$ 末満を young, $4 \%$ 以上 7 \%末満を mature, $7 \%$ 以上を aged 上定義し ているが，1985年現在わが国の65歳以上高龄者 人口は 1241 万人で総人口（1 億 2094 万人）の $10.3 \%$ 占め，2015年（昭和90年）には $20 \%$ を 超えると予想される. 欧米諸国で現在高龄者 人口が $10 \%$ 超えているのは 1 位スエーデン (16.6\%)， 2 位西ドイツ (15.0\%)，3位イギ リス (14.9\%)，4位イタリア (13.6\%)，5位。 フランス (13.0\%), 6 位アメリカ (11.6\%), 7 位力ナダ $(10.0 \%)$ でわが国は 7 位のカナダ 亡肩を证べているが，21世紀初めにはスエーデ ンと並んで世界一となる筈である．1985年現 在, 65 藏以上の就業人口は 290 万人で全就業者 の $5.0 \%$ 占阮てい。現実には就業希望者は もっとあろうが雇用側の問題むあり低く抑えら れているとみるべきである，わが国は着実に超 高榆化社会へと進み始め，乙のことは公的年金 の財政，医療費など国氏経済におよぼす影響は 䒚大であり，長店のつけは確実にまわってくる というべきである。しかし，ての流れは避けて 通ることのできないものである以上，すべての 国民が冷静にうけと好て立ち们かわねばならな い、日本の繁樂は一依にしてできたものではな く, 現在高歯者とよばれる人々の努力によって 築きあげられたものである。無病長寿者む䄆長 期生存者屯人間としての生き甲斐，不自然でな い延命, 生活保障, 健冰管理などあたたかい施 策が必要である。

白石 ${ }^{10)}$ は人生 80 年侍代を迎えた今日, 80 歳代 の死亡パターンをむって日本人の典型的死亡パ ターンと見做すことができるとし，80歳代では 脳血管娭患が $25.0 \%$ と焣高（1月最高，6月 最低), 心宛患 $22.2 \%$ ( 1 月最高, 6 月最低), 昰性新生物 $12.7 \%$ (月别変動なし), 肺炎およ び気管支炎 $9.7 \%$ ( 2 月, 8 月最高, 6 月最 低)，精神病の記載のない老衰 $8.5 \%$ （1月最 高, 6 月最低) で, 覀性新生物部位別では胃
$30.2 \%$ (男 $31.3 \%$ ，女 $29.0 \%$ ，気管，気管支 および肺15.2\%（男19.5\%，女10.4\%)，80歳 代にことに多いものは前立腺, 膀胱の恶性新生 物であると述べ，80歳に達した人が，その後さ らに10年生存し，90歳に達する確率を求全国 平均では男 $20.03 \%$ ，女 $29.12 \%$ ，つまり男では 80 歳の 10 人に 2 人，女では 10 人 3 人が 90 歳まで 生き得ると報告している。自験例での死亡時の 年柃では 80 歳代 4 例あり, 現在生存例では70歳 代 7 例で 80 墄代はないが, 今後, 癌を克服した 人がさらに80歳, 90 歳と生存する可能性は充分 考えられるので80歳代の死亡内容を分析し, 留 意点を見つけあたたかく見守るべきである.

病理組織学的には表 6 のごとく扁平上皮癌54 例 $(91.5 \%)$, 腺様のう胞癌 4 例 $(6.8 \%)$, 乳 䫓状腺渻 1 例で, Grade ( I , II ) 42例（77.8 \%)上多くみられた. Grade 分布は全症例の それと比して大符なかった。長期生存例の臨床 病理学的検討で佐久間ら ${ }^{11}$ は胃癌にて 10 年以上 生存した進行胃癌 232 例之 5 年以内に死亡した 治療切除例 287 例の対比にて, 肉眼癌型では両 者に算はなく, 組織型で 5 年以内死亡例では乳 竨腺癌 $7.5 \%$ ，高分化腺澢 $0.8 \%$, 川分化腺癌 $29.2 \%$ ，低分化腺澏 $62.5 \%$ ，一方，10年生存例 ではそれぞれ $14.2 \%, 1.5 \%, 27.6 \%, 56.7 \%$ て 5 年以内死亡例に若斗低分化腺澏が多いものの 統計学的に有意差なく，浸潤様式にもまったく 差はなかったとしている。上顎洞癌の塕合も長 期経過例之他の群との間に病理組織学的に特微 ある所見を見出すことはできなかった。

現在生存症例の初回治療は表 7 にみごと く, 当科に打ける上顎洞癌治療の流れを示し, 全摘出単独 4 例 $(12.9 \%)$ ，全摘出＋照射 5 例 $(16.1 \%)$ ，照射単独 3 例 $(9.7 \%)$ ，三者併用 11例 $(35.5 \%)$, 照射 +化学療法 3 例, 減量手 術十照射 5 例で，うち再発 1 例は小線源にて, 頸部転移 1 例は頸部部清術にて制御し, 以後良 好な経過をとっている，初診特進展Nのないて と，体力充分で治療に耐えられたてと，全身

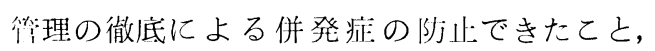


follow up の完储により早期に再発，転移を見 出し得たこと, 家人の協力, 本人の意欲などす べてが lucky な西僋いた人達の集まりであ るかも知れないが, 患者をとりまく人々（家 族，職場関係，医療従事者など）の果した力は 大きい.

5 年以上経過死亡例の $75 \%$ は他而死であり， 腫瘍死は 7 例 $(25 \%) ，$ う5 5 例は加療後 5 〜 7 年の間に拝中している（表 8 ）。厚生少「人口 動態統計」によれば墨性新生物は炤和56年死亡 原因の第 1 位となり, 第 2 位は脳血管疾患, 第 3 位は心疾患という順位がつづいているが第 3 位心疾患はゆるやかに上昇し，第 2 位との差を ちぢめつつあり，炤和59年には人口107j対死亡 率は脳血管疾患 119.6 , 心疾患 116.3 (死亡数で は 4000 人の差) で間もなく 2 位と 3 位の逆転が おこると予想される．かくのごとき現状より， 首尼よく上顎润癌を克服して 5 年以上経過した 人達が不幸にして脳血管疾患, 心娭患にて倒れ ることも充分予期され，今後の大きな閌題とな るであろう。湏頸部癌にても 5 年生存率で議論 するととより脱却し，10年生存率，15年生存率 を問題とする際にはことさらである。いかに他 病死を防ぎ天寿を全うさせるか，公的健康管: 理，本人のたゆま湕康への関心，すぐに対応 できる高柃者専用医療機関の増設, 手荤れとな らないよう経済面での配虑, 単に生きていると いうだけではなく年柃, 体力に忍じた仕事をし ながらの張りのある生活など精神的, 肉体的に 健逯に年をとるためにしなければならないこと は多い，いまだ難治疾患である上顎润癌を兌服 し,やっと癌の恐怖からのがれた人々に安定し た老後の人生を送らせること，それが私共の最 大の贈物である.

5 年経過後死亡例 28 例の初回治療は表 9 のご とく, 全护出 3 例 $(10.7 \%)$, 全摘出 + 照射 9 例 $(32.1 \%)$, 全摘出 + 化療 2 例 $(7.1 \%)$, 照 射 6 例 $(21.4 \%)$, 照射 + 化療 3 例, 三者併用 4 例 (14.3\%), その他 1 例であり, 再発, 枟 移率はそれぞれ $0 \%$ ，66.7\%，0\%，50.0\%，
$66.7 \%, 75.0 \%, 0 \%$ あった。再発（11例） までの剘間は治療終了後 4 か月（2 例）， 7 か 月 ( 3 例), 1 年 2 出月 ( 1 例), 2 年 3 名月 ( 1 例), 2 年 5 加 ( 1 例), 2 年 6 吕月（1 例)， 3 年 1 出月（1例），4年 5 分月（1例） であり，頸部転移（2例）までの期問は 4 か 月， 5 か月各 1 例，肺転移は 5 年 2 か月の 1 例 である。既報告例 ${ }^{12}$ に拈ける上顎润癌再発74例 の検討では原発榡治療終了後再発までの期間は 6 か月以内 36 例 $(48.6 \%)$ とほぼ半数を占め, 1 年以内では 58 例 $(78.4 \%)$ と大半を占める が，長剘経過例では 6 か月以内 $18.2 \% ， 1$ 年以 内 $45.5 \%$ とほぼ半数之なり, 再発までの期問が やや長い傾向がみられた。再発，転移の治療は 表10のごとく二次治療施行により 10/14（71.4 \%) の制御率，うち 4 例に三次治療を必要とし た。 そのうちわけは照射十化療 (制御), 照射 (非制御)，照射十化療 (非制御)，凍結術 (非 制御）で，1例のみ制御し得た。なお，二次治 療終了より三次治療開始までの期間は 12 年 4 か 月， 4 年， 7 年 8 か月， 2 年 4 か月であった.

再発侍の対応の仕力は初回治療内容により異 なるが原則として機能と形態を極力保持してそ の治療に努めた。すなわち，小範囲再発ならば 小線源のみにて治療し，つぎの段階では上顎掻 爬に放射線治療の組み合せ，初回治療内容によ っては外照射のみにとどめたものもあり，全摘 出屯適宜施行するというのが全般を通じてのう 針である.乙の才針で $63.5 \%$ 再発制御率を得 ているが ${ }^{12)}$, 今回の長期経過例では $71.4 \%$ あ った.

再発癌のとらえ才として古江 ${ }^{13)}$ は再発癌は癌 患者の臨末経過のなかにあって根治可能, 根治 不能，そして再発という線上にあるのではな く, 血色素量, 赤血球数, リンパ球数, T細胞 数, PHAによるリンパ球の幼若化率, IgG, IAP (immuno suppressive acidic protein) などの項目について再発癌は根治可能例と不能 例の川間というよりむしろ根治可能例に近い方 に位置する。すすなおち再発例は原発巣を有する 
根治不能例上り屯病態牛理学的，负疫学的飞対 して屯集学的，体系的に积敬的治康少行われる べきであるとしている。

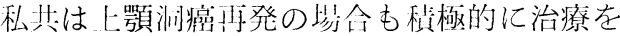
行ったが，根底には機能と形態の保持という一 本の線はつら奴もりである.

治療後長期問経ての再発，忶移のメカニズム は不明であるが，再発までの剘閂は短期問であ ると限定する必要はなく，長期問潜在したもの

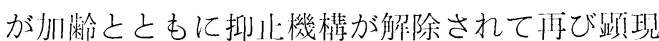
性を回後したとみたい。

再発の概念之は少し異るが小野ら ${ }^{14)}$ の予後不 块（2年以内に40\%死亡'）とされる恐性線維性 紅織球腫（MF H）が15年䦥の長期にわたって

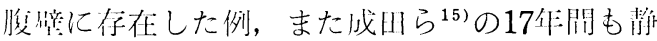
在していた乳闺の腙様のう胞癌例のごとく悲性: 腫愓でも必ずしも掌に成長発育をつづけるとは

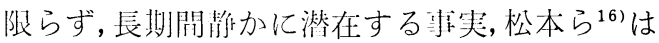
紧細胞癌摘除後24年目に脛鱼に転移した症例を 報告し，5年生存率20４5\%と不这な等絒胞癌 のなかには奇妙な隐床経過をとるもののあるこ と老述べ，1）原発森手術後，長期問を経て原 発准に近く局䜣再発するもの2 )原発栄手術後

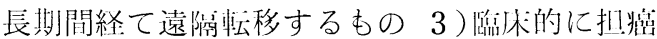

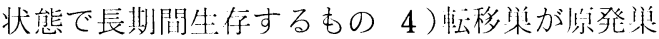
の手術により消失するものを登げ，桜㺕の治療 には長期閂の follow up 在必要とし，また， いかに長期間経てい上うと屯再発，沇移の问能 性を常に考虑すべきであるとしている.

これは上顎洲嵒治療後の患者の follow の際 にああてはまると想わ机る。

大出ら ${ }^{17}$ の胃嵒除後23作目に再び残胃に新た に発生した癌の例など㠙発生:のメカニズムにつ いてはまだまだ不明な点が多い。

さらに涌谷ら $\left.{ }^{18}\right)$ は上顎癌根治于術後25作䦌経 過して局所に再発した症例を報告し， $\mathrm{Ra}$ 㴦内 热射により般痕組織化した局沂に25年閭潜伏し

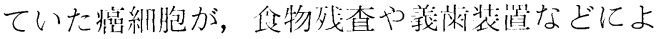
り局所刺激ひいては慢性炎楅の発生:が频现性を 回復する引き金となったと述べている。いづれ
にせよ癌の長期䦌潜伏，なんらかの唀内による

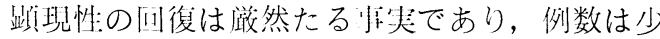
ないとはいえ柋者にとってもわ执机とって

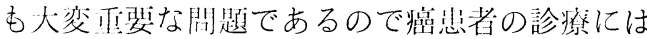
管にてのことを念韻に打いてあたらねばならな い.

$\mathrm{T} 3 \mathrm{~N} 0$ 症例を進展广们より 7 つに分類し生 存成績をみた既報告例 ${ }^{199}$ では下内才型を筆识之

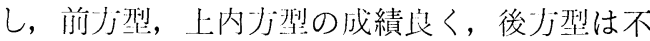
应似向にあった。同じ准展度を示す T 3 症例で はほぼ同じ予後を示すのが理想的ではあるが， 症例数の尷いもあり途中経過においてはバラッ キを六したが 5 年の岮点でみる服りほぼ同一籁

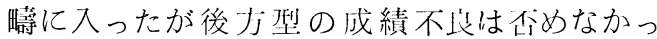
た。しかしながら（表12）にみるごとく，予後 不桹とさ机る後力型，全方们型でも垃則生:存例 は存在しうるので治療は微底してなさるべきで ある。

上顎润癌というきわめて耀治な疾患を兑服し 5 年以上䋂過した人々，ともすれば殿画な監视 の目からはずれがちなこの壮剘の人々にこそあ たたかい日がそそがれねばならない。

\section{まとめ}

刀療後 5 年以上経過した上䕱润癌症例を他部 位癌長期生存例之の対比により分析し，あわせ て今や超高秢化社会となったわが日本における 長期生:存嵒忠者の上り扱いについて述べた。

本論文の要旨は第47回耳鼻咽喉科臨床会総会（昭和 60年 6 月29日）において発表した。

\section{文献}

1) 酒井俊一：上顎洞癌の治橑一トライアルの積み重

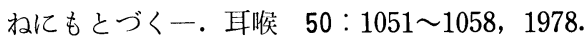

2 ）堀内㴡一，他：口腔癌放射線治燎後の長期生存例 の予後. 癌の臨床 $30 ： 1855 \sim 1860,1984$.

3 ）晴山雅人，他：放射線単独治獠に上る食道癌 5 年 以上無期生存例の検討. 癌の臨床 $30 ： 885 \sim$ 890, 1984.

4) 楠元志都生, 他：肺小細胞癌長期生存の 1 例. 癌 の臨床 31：323〜326，1985. 
5 ）中野隆史, 他：早期食道癌に対する放射線単独治 療による根治可能性の検討. 癌の臨床 $31: 236$ $\sim 239,1985$.

6) 小池聰之, 他：肺転移後 8 年間生在した上顎癌 (adenoid cystic carcinoma) の 1 例一当院上 顎非扁平上皮癌 6 剖検例の検討一. 癌の臨床 31 : 552 558, 1985.

7 ) 小島晴洋：「対がん10ケ年総合戦略」について. 厚生の指標 $31: 47 \sim 53,1984$.

8 ）紀藤 毅：高齢者胃癌の手術成績. 外科治療 52 : 361 365, 1985.

9 ）菱沼従尹：80歳台上の初眺望一1984年簡易生命 表のプロフィール. 厚生の指標 $32: 3 \sim 8$, 1985 .

10）白石昌嵩：高稌者の死亡. 厚生の指標 $32 ： 9$ 〜 $13,1985$.

11）佐久間晃, 他：胃癌切除後 10 年生存例の臨床病理 学的検討. 癌の臨床 $29: 887 \sim 890,1983$.

12）近藤 隆, 河辺義孝：上顎癌再発症例の検討. 耳 鼻臨床 $74: 461 \sim 469,1981$.

13）古江. 尚：再発癌の治療一総論一. 癌と化学療法
$10: 2281 \sim 2285,1983$.

14）小野隆男：15年間腹壁に限局していた悪性線維 性組織球腫の 1 例. 外科診療 $27 ： 124 \sim 130$, 1985.

15）成田達彦：17年間の病悩期間を有した乳房腺様の う胞癌の 1 例. 外科診療 $27: 96 \sim 99,1985$.

16）松本誠一，他：腎摘後 24 年目に骨転移が明らかと なった腎細胞癌の 1 例. 癌の臨床 $30 ： 965 ９ 67$, 1984.

17）大出淔弘, 他：胃癌切除後 23 年目に再切除したい わゆる残胃の癌の 1 例と本邦報告例の検討. 外科 治療 $52 ： 118 \sim 123,1985$.

18）涌谷忠雄, 他：上顎癌の晚期再発症例. 耳喉 47 : 635 641, 1975.

19）近藤 隆，河辺義孝：進展度および進展方向によ る上顎癌症例の分析. 耳鼻臨床 $74: 823 \sim 838$, 1981.

原稿到着：昭和60年10月15日 別刷請求先 : 近藤 隆 T464 名古屋市千種区田代町鹿子殿81-1159 愛知がんセンタ一病院頭頸部外科 